\title{
The evaluation of diagnostic performance of some enzymes for diagnosis and detection of breast cancer by ROC curve
}

\author{
Halit Demir $^{1 *}$ Sıddık Keskin ${ }^{2}$, Canan Demir ${ }^{3}$, Halis Gokyer ${ }^{1}$
}

\begin{abstract}
Objective: In this study, it was aimed to examine the performance of Arylesterase (ARE), Paraoxonase-1 (PON1) and Adenosine deaminase (ADA) enzymes to identify cancer patients and their stages with ROC curve in serum samples taken from patients diagnosed as breast cancer in the Medical Oncology services at Yüzüncü Y1l University.
\end{abstract}

Material and Methods: The 25 healthy controls and 25 breast cancer patients are included in this study. 8 patients are in stage-1, 9 patients are in stage- 2 and 8 patients are in stage-3. Adenosine deaminase (ADA), Paraoxonase-1 (PON-1) and Arylesterase (ARE) activities were detected in serums with Spectrophotometric method. Descriptive statistics for the traits studied were presented as median, mean, standard deviation, minimum and maximum value. In terms of these traits, Kruskal-Wallis test was performed to find out whether there are no differences between stages and control group. In addition, ROC analysis was performed to evaluate the performances of enzymes to classify patient and control group.

Results: The differences between stage-1, stage-2, stage-3 and control group for Adenosine deaminase (ADA) enzyme activities were found statistically significant $(\mathrm{p}<0.01)$. Besides, the difference between stage- 2 and stage3 was found insignificant for Paraoxonase-1 (PON-1) and Arylesterase (ARE) enzyme activity. Last, the difference between them and stage-1 and control group was found statistically significant.

Conclusion: It can be inferred that sensitivity and specificity values of the enzymes are favorable high and they have outstanding performance to identify tumor stage as well as patient and control group. Therefore, these enzymes should be suggested as a "diagnostic test" to classify patients with breast cancer and control group.

Key words: Arylesterase, adenosine deaminase, sensitivity, specificity.

\section{Introduction}

Cancer is a serious disease which is the result of cells' abnormal growth, multiplying out of control, spreading to other tissues and which results mostly in death. Cancer causes non-functionality of the organs and body. The exact reasons are unknown yet. However, there are two risk factors for this disease. While the first group risk factor depends on age, gender, lifestyle and family history; the second one consists of environmental factors. Cigarette, use of alcohol, air pollution, some viruses, exposure to extensive sunlight, overdose radiation and $\mathrm{X}$ - rays, and chemicals such as benzene, coloring materials and asbestos can be ranked among these environmental factors. It is stated that after lung cancer, breast cancer (\%23) occurrence in women is the second most common kind of cancer in the world $(1,2)$.
One out of every eight women is under the risk of getting cancer according to a research conducted in the US in 2011 (3).

There are some tumor markers, such as carcinoembryonic antigen (CEA) alpha-fetoprotein (AFP) calcitonin (CT) and alkaline phosphatase (ALP) to evaluate parenchyma. In other words, tumors respond to treatment and to detect metastasizes early (4). In breast cancer, the decrease in superoxide dismutase (SOD) and antioxidant enzyme (catalase) activity was detected. In the same study, it is reported that there is a correlation between the increase in blood lipid peroxidation and SOD and decrease in catalase activity (5, 6). Paraoxonase-1 (PON-1), which is calcium-dependant ester hydrolase in glycoprotein structure, is an enzyme which has both arylesterase

Received 19-04-2016 Accepted 20-05-2016 Available Online 15-06-2016

1 Yuzuncu Yil University, Faculty of Science, Department of Chemistry/Biochemistry-Van, Turkey

2 Yuzuncu Yil University, Faculty of Medicine, Department of Biostatistics-Van, Turkey

3 Yuzuncu Yil University, Vocational School of Health Services-Van, Turkey

* Corrospending Author: Halit Demir E-mail: halitdemi@gmail.com Phone: +904322251806 
(ARE) (E.C. 3.1.1.2) and paraoxonase (E.C.3.1.8.1) serum activity $(7,6)$. Adenosine deaminase (ADA) is a key enzyme in mammal purine salvage pathway and catalyses the inosine transformation of adenosine (6). In recent studies, it has been reported that oxidative stress emerging with regard to the changes in the level of prooxidant-antioxidant in patients with breast, colon and prostate cancer is related to malign diseases (6).

Diagnostic tests used in medicine to make decisions are generally laboratory tests or observations or measurements made via devices. Clinical performance of a diagnostic test is evaluated with general accuracy rate or according to whether or not it classifies ill individuals as "ill" and healthy individuals as " healthy". Most of the laboratory findings used for diagnosis of many diseases is biochemical traits which have are continuous variables. As a diagnostic test, in order to find out continuous variable performance, ROC (Receiver operating characteristic) curve is one of the commonly used methods to classify ill and healthy individuals by detecting cut-off points. ROC is the curve which is obtained by taking measured value of continuous variable as cut-off points and with marking Sensitivity level on $\mathrm{Y}$ axis, 1- Specificity level on $\mathrm{X}$ axis. The total area under the curve is " 1 ". This indicates that classification power of the trait is $100 \%$. However, when the area under the curve is 0.50 , this means that there is no classification power for the trait. ROC curve summarizes accuracy of the test with a numerical value.

In this study, it was aimed to examine the performance of Arylesterase (ARE), Paraoxonase-1 (PON-1) and Adenosine deaminase (ADA) enzymes to identify cancer patients and their stages with ROC curve in serum samples taken from patients diagnosed as breast cancer in Yüzüncü Yıl University Medical Oncology services.

\section{Material and Methods}

The data of this study were taken from the study conducted by Gökyer (2015) (6). 25 healthy controls and 25 breast cancer patients are included in the study. 8 patients are in stage- 1,9 patients are in stage- 2 and 8 patients are in stage-3. Before taking blood samples, the approval of Yüzüncü Y1l University, Medical Faculty, Education and Research and Application Hospital Clinic and Laboratory Research Local Ethics Committee was received. $3 \mathrm{ml}$ venous blood samples were taken from each patient involved in the study. These samples were centrifuged in $5000 \mathrm{rpm} / \mathrm{min}$ for nearly ten minutes and serums were separated and Adenosine deaminase (ADA), Paraoxonase-1 (PON1) and Arylesterase (ARE) activities were detected in serums with Spectrophotometric method.
Statistical Analysis: Descriptive statistics for the traits included in the study was presented as median, mean, standard deviation, minimum and maximum value. For these traits, Kruskal-Wallis test was performed to find out whether there are any differences between stages and control group. In addition, ROC curve analysis was also carried out to evaluate the performances of enzymes to identify the patient and control group. Statistical significance level was considered as 5\% and SSPS (ver: 13) statistical software was used for all statistical computations.

\section{Results}

Descriptive statistics and comparison results are given in Table 1 for Arylesterase (ARE), Paraoxonase-1 (PON-1) and Adenosine deaminase (ADA) enzyme activities. As shown in Table 1, the differences between stage-1, stage-2, stage-3 and control group for Adenosine deaminase (ADA) enzyme activities were found statistically significant $(\mathrm{p}<0.01)$. While the difference between stage-2 and stage-3 was not significant for Paraoxonase-1 (PON-1) and Arylesterase (ARE) enzyme activity, the differences of these from stage -1 and control group was found (statistically) significant. Accordingly, mean value of Adenosine deaminase (ADA) enzyme activity was found 24.89 EU/L. Mean values were found 37.41 $\mathrm{EU} / \mathrm{L}$ in stage-1, 45.07 EU/L in stage-2 and 58.34 $\mathrm{EU} / \mathrm{L}$ in stage-3. When the mean values of Paraoxonase-1 (PON-1) enzyme activity were considered, these values were $4.46 \mathrm{EU} / \mathrm{L}$ in stage-1, $0.51 \mathrm{EU} / \mathrm{L}$ in stage-2 and $0.25 \mathrm{EU} / \mathrm{L}$ in stage-3, while $13.11 \mathrm{EU} / \mathrm{L}$ in control group. Arylesterase (ARE) enzyme activity means were $236.38 \mathrm{kEU} / \mathrm{L}$ in control group, $41.68 \mathrm{kEU} / \mathrm{L}$ in stage-1, $1.32 \mathrm{kEU} / \mathrm{L}$ in stage-2 and $0.18 \mathrm{kEU} / \mathrm{L}$ in stage- 3 .

Table 1. Descriptive statistics and comparison results

The results of ROC analysis conducted to evaluate the performance of Adenosine deaminase (ADA) enzyme for the classification of healthy and diseased individuals and the stages of diseased individuals from each other are given in Table 2. One of the criterions to evaluate the performance of the tests for giving the true positive decision is the area under the ROC curve. This area ranges from the value of maximum 1 to minimum 0.5. The area under the ROC curve was found 0.987 for patient and control-group in Table 2 . While this value was found 0.960 for stage -1 and stage -2 , the areas under the curve were 1 for the other groups. For determining the best cut-off point values by means of ROC curve, these values are observed as 34.039 for patient and control-group, 42.380 for stage1 and control-group, 47.805 for stage- 2 and controlgroup, 51.411 for stage -3 and control-group, 34.039 for stage- 1 and stage $-2,40.126$ for stage- 1 and stage$3,45.55$ for stage-2 and stage- 3 . 
Table 1. Descriptive statistics and comparison results

\begin{tabular}{|c|c|c|c|c|c|}
\hline \multicolumn{2}{|c|}{ Groups } & \multirow{2}{*}{$\frac{\text { Stage-1 }}{36.07 \mathrm{c}}$} & \multirow{2}{*}{$\frac{\text { Stage-2 }}{44.64 \mathrm{~b}}$} & \multirow{2}{*}{$\frac{\text { Stage-3 }}{5058}$} & Control \\
\hline \multirow{4}{*}{$\begin{array}{c}\text { Adenosine deaminase } \\
\text { (ADA) }\end{array}$} & Median & & & & $24.35 \mathrm{~d}$ \\
\hline & Mean \pm SD & $37.41 \pm 3.42$ & $45.07 \pm 1.87$ & $58.34 \pm 3.59$ & $24.89 \pm 7.88$ \\
\hline & Min. & 34.27 & 42.83 & 53.68 & 14.43 \\
\hline & Max. & 41.93 & 49.14 & 64.68 & 37.42 \\
\hline \multirow{4}{*}{$\begin{array}{r}\text { Paraoxonase-1 } \\
\text { (PON-1) }\end{array}$} & Median & $5.12 \mathrm{~b}$ & $0.48 \mathrm{c}$ & $0.24 \mathrm{c}$ & $13.42 \mathrm{a}$ \\
\hline & Mean \pm SD & $4.46 \pm 3.22$ & $0.51 \pm 0.16$ & $0.25 \pm 0.16$ & $13.11 \pm 2.07$ \\
\hline & Min. & 0.78 & 0.30 & 0.06 & 10.11 \\
\hline & Max. & 9.35 & 0.78 & 0.54 & 17.45 \\
\hline \multirow{4}{*}{$\begin{array}{l}\text { Arylesterase } \\
\text { (ARE) }\end{array}$} & Median & $21.85 \mathrm{~b}$ & $1.45 \mathrm{c}$ & $0.13 \mathrm{c}$ & $228.56 \mathrm{a}$ \\
\hline & Mean \pm SD & $41.68 \pm 43.40$ & $1.32 \pm 0.42$ & $0.18 \pm 0.07$ & $236.38 \pm 34.72$ \\
\hline & Min. & 1.84 & 0.66 & 0.13 & 198.95 \\
\hline & Max. & 112.52 & 1.84 & 0.26 & 335.43 \\
\hline p & & 0.01 & 0.01 & 0.01 & 0.01 \\
\hline
\end{tabular}

Table 2. Results of ROC analysis for ADA

\begin{tabular}{llcllll} 
Groups & Cut-off value & The area under the curve & Std. Error & Sensitivity & Specificity & $\mathrm{p}$ \\
\hline Patient- Control & 34.039 & 0.987 & 0.011 & 1.000 & 0.920 & 0.001 \\
Stage 1-Control & 42.380 & 1.000 & 0.001 & 1.000 & 1.000 & 0.001 \\
Stage 2- Control & 47.805 & 1.000 & 0.001 & 1.000 & 1.000 & 0.001 \\
Stage 3- Control & 51.411 & 1.000 & 0.001 & 1.000 & 1.000 & 0.001 \\
Stage 1- Stage 2 & 34.039 & 0.960 & 0.032 & 1.000 & 0.920 & 0.001 \\
Stage 1- Stage 3 & 40.126 & 1.000 & 0.001 & 1.000 & 1.000 & 0.001 \\
Stage 2- Stage 3 & 45.550 & 1.000 & 0.001 & 1.000 & 1.000 & 0.001 \\
\hline
\end{tabular}

Table 3. Results of ROC analysis for PON-1

\begin{tabular}{lcccccc} 
Groups & Cut-off value & The area under the curve & Std. Error & Sensitivity & Specificity & $\mathrm{p}$ \\
\hline Patient - Control & 9.730 & 1.000 & 0.001 & 1.000 & 1.000 & 0.001 \\
Stage 1- Control & 0.750 & 0.993 & 0.011 & 1.000 & 0.890 & 0.001 \\
Stage 2- Control & 0.660 & 1.000 & 0.001 & 1.000 & 1.000 & 0.001 \\
Stage 3- Control & 0.240 & 0.882 & 0.086 & 1.000 & 0.500 & 0.008 \\
Stage 1- Stage 2 & 9.730 & 1.000 & 0.001 & 1.000 & 1.000 & 0.001 \\
Stage 1- Stage 3 & 5.445 & 1.000 & 0.001 & 1.000 & 1.000 & 0.001 \\
Stage 2- Stage 3 & 5.325 & 1.000 & 0.001 & 1.000 & 1.000 & 0.001 \\
\hline
\end{tabular}

Table 4. Results of ROC Analysis for ARE

\begin{tabular}{lcccccc} 
Groups & Cut-off value & The area under the curve & Std. Error & Sensitivity & Specificity & $\mathrm{p}$ \\
\hline Patient- Control & 155.735 & 1.000 & 0.001 & 1.000 & 1.000 & 0.001 \\
Stage 1- Control & 1.710 & 0.993 & 0.014 & 1.000 & 0.890 & 0.001 \\
Stage 2- Control & 1.052 & 1.000 & 0.001 & 1.000 & 1.000 & 0.001 \\
Stage 3- Control & 460 & 1.000 & 0.001 & 1.000 & 1.000 & 0.001 \\
Stage 1- Stage 2 & 155.735 & 1.000 & 0.001 & 1.000 & 1.000 & 0.001 \\
Stage 1- Stage 3 & 100.397 & 1.000 & 0.001 & 1.000 & 1.000 & 0.001 \\
Stage 2- Stage 3 & 99.607 & 1.000 & 0.001 & 1.000 & 1.000 & 0.001 \\
\hline
\end{tabular}

According to these cut-off values, it can be noted that the sensitivity of the test which is the ability to identify the individuals as patient equal " 1 " for all groups. The specificity value of the test, which is the ability to identify the individuals as healthy, is 0.920 for patient and control-groups and stage- 1 and stage- 2 . However, this value is 1 for the other groups.

For Paraoxonase-1 (PON-1) enzyme activity, ROC analysis results concerning patient and control groups along with patients' stages are given in Table 3 . While considering Table 3 , it can be stated that the area under the curve is 0.993 for stage- 1 and control-group, 0.882 for stage- 3 and control-group and 1 for the other groups. Accordingly, the best cut-off point values were found 9.730 for patient and control group, 0.750 for stage- 1 and control group, 0.660 for stage- 2 and control group, 0.240 for stage- 3 and control group, 9.730 for stage- 1 and stage-2, 5.445 for stage- 1 and stage- 3 and 5.325 for stage- 2 and stage-3. According to these cut-off values, while sensitivity was found 1 for all groups, specificity values were recorded as 1 for the other groups except stage- 1 and control group (0.890) and stage-3 and control group (0.50). 
For Arylesterase (ARE) enzyme activity, results of ROC analysis concerning patient and control groups along with patients' stages are given in Table 4 . Findings in Table 4 indicate that the area under curve is 1 for the all groups excepting for stage- 1 and control group. Accordingly, the best cut-off values were found 155.735 for patient and control group, 1.710 for stage- 1 and control group, 1.052 for stage- 2 and control-group, 0.460 for stage-3 and control group, 155.735 for stage- 1 and stage-2, 100.397 for stage- 1 and stage-3 and 99.607 for stage-2 and stage3 . Sensitivity values of the diagnostic test were found 1 for all groups and specificity values were found 1 for all groups except stage-1 and control group (0.890).

\section{Discussion}

Although cancer occurs as a result of malignant transformation of the cells, there is very little difference between normal and cancer cells in terms of genotypic expression. The mutations causing cancer are unlikely to be able to change either genetic or phenotypic expression except cell growth regulation. Breast cancer is a type of cancer that forms in breast tissue and differs significantly between geographical regions. The incidence of breast cancer is more frequent in developed countries compared to less developed countries in East Asia. When categorized in terms of age, the rate of getting breast cancer is 76.7 in one hundred thousand in North America while this rate is 23.5 in one hundred thousand in East Asia (8). According to scientific studies, the rate of getting breast cancer is higher in low-income countries and the women in those countries are under bigger risk.

In biological and biochemical systems; catalase (CAT), arylesterase (AR), paraoxonase-1 (PON-1), peroxidise (POD), glutathione reductase (GR) and superoxide dismutase (SOD) are enzymes which have antioxidant effects. Antioxidant defense system protects cell from the oxidative damage of free radical or other reactive molecules. For this reason, antioxidant enzymes such as CAT, PON-1, ARE, GR and SOD have great importance in defense system. Detrimental effects of free radicals are controlled by antioxidant defense systems in cells $(9,6)$. In a study on breast cancer, serum PON-1 activities in patients were found lower compared to control-group (10).

Again, in a literature review, ADA activity was found higher in breast cancer patients compared to healthy control group (11). In literature, the activity of ARE may be a useful for study clinical in breast cancer (12).

\section{Conclusion}

ROC curve is one of the commonly used methods to evaluate any diagnostic tests, determine the most appropriate cut-off value and determine the efficiency of the test depending upon this value. In addition to numerical values, graphical presentation contributes to interpretation of the results.

It can be concluded that sensitivity and specificity values of the enzymes are favorable high and they have outstanding performance to identify tumor stage as well as patient and control group. Therefore, these enzymes should be suggested as a "diagnostic test" to identify breast cancer patients and control group.

Conflict of Interest: The authors declare no potential conflicts of interest with respect to the research, authorship, and/or publication of this article.

Ethical issues: All Authors declare that Originality of research/article etc... and ethical approval of research, and responsibilities of research against local ethics commission are under the Authors responsibilities. The study was completed due to defined rules by the Local Ethics Commission guidelines and audits.

Acknowledgments: None

Author Contributions: H D: Hypothesis and design, S K: Hypothesis and Statistical Analysis, C D: Sample collection and tests, H G: Sample collection and tests

\section{Reference}

1. Greenlee RT, Murray T, Bolden S. Cancer Statistics. Cancer J Clin. 2000; 50: 7-33.

2. Ayhan F, Yorgancioğlu R. Meme Kanseri ve Rehabilitasyon. Türkiye Klinikleri J Int Med Sci. 2006. 2: 39-48.

3. Saip, P., Keskin, S., Özkan, M., Kaplan, M.A., Aydoğan, F., Demirağ, G.G., Uzunoğlu, S., Engin, H., Başaran, G., Güler, N., Uygun, K., Demirkan, B.,Özdemir, F., Çubukçu, E., Salepçi, T., Çiçin, İ. Türkiye'de Meme Kanserli Hastaların Tanı ve Tedavi Yöntemlerine Ulaşım Hızı; Çok Merkezli Gözlemsel Çalışma. Meme Sağlığı Dergisi. 2011; 7:2.

4. Meram İ, Sibel A, Tarakçıoğlu M. Kanserde Serum Arginaz Aktivitesi. Van Tıp Dergisi. 2000;7 (1): 20-23.

5. Kumaraguruparan R, Subapriya R, Kabalimoorthy J and Nagini S. Antioxidant profile in the circulation of patients with fibroadenoma and adenocarcinoma of the breast. Clin. Biochem. 2002; 35: 275-279.

6. Gökyer H. Meme Kanserli Hastalarda Adenozin Deaminaz, Aril Esteraz ve Paraoksanaz-1 Serum Aktivitelerinin İncelenmesi (Yüksek Lisans Tezi). YYÜ, Fen Bilimleri Enstitüsü. 2015. Van.

7. Durrington PN, Mackness B, Mackness MI. Paraoxonase and Atherosclerosis. Arterioscler Thromb Vasc Biol. 2001; 21 (4): 473-80.

8. Ferlay J, Shin HR, Bray F, Forman D, Mathers C, Parkin DM. Cancer Incidence and Mortality Worldwide: IARC Cancer Base No. 10 [Internet]. Lyon, France: International Agency for Research on Cancer. 2008, 2010. Available from:URL:http://globocan.iarc.fr. 
9. Gülçin I. Isırgan Otunun (Urtica dioica) Antioksidan Aktivitesinin Belirlenmesi, Oksidatif Enzimlerin Karakterizasyonu ve Bazı In vivo Etkilerinin İncelenmesi (doktora tezi). A.Ü, Fen Bilimleri Enstitüsü. 2002. Erzurum.

10. Balcı H, Genç H, Papila C, Can G, Papila B, Yanardağ H, Uzun H. Serum lipid hydroperoxide levels and paraoxonase activity in patients with lung, breast, andcolorectalcancer. J.Clin.LabAnal. 2012; 26 (3): 155-60.
11. Al-Rubaye F, Morad T. Serum adenosine deaminase activity in Iraqi patients with breast cancer on tamoxifen therapy. Gaziantep Med J. 2012; 18 (3): 139-142.

12. Bobin-Dubigeon C, Lefrançois A, Classe JM, Joalland MP, Bard JM. Paired measurement of serum amyloid A (SAA) and paraoxonase 1 (PON1) as useful markers in breast cancer recurrence.Clin.Biochem.2015;48(16-17):118132010;7:647-52.

Copyright (C) 2016 The Author(s); This is an open-access article distributed under the terms of the Creative Commons Attribution License (http://creativecommons.org/licenses/by/4.0), which permits unrestricted use, distribution, and reproduction in any medium, provided the original work is properly cited. All Rights reserved by international journal of Medical Science and Discovery. 